\title{
PENENTUAN AWAL BULAN KAMARIAH PERSPEKTIF SYAR'I DAN ILMU PENGETAHUAN
}

\author{
Oleh : \\ Subaidi ${ }^{1}$ \\ Fakultas Syariah IAI Ibrahimy Situbondo \\ subaidishalli@yahoo.co.id
}

\begin{abstract}
:
The start of the month kamariyah not be done except by rukyatul hilal, either with the naked eye or with the aid of a tool, not the reckoning. Rukyatul is applicable rukyatul global (applies to all Muslims), not the new moon rukyatul applicable locally or regionally on the basis of the concept of mathla'; Is the benchmark rukyatul hilal is rukyatul ruler of Mecca, not absolute rukyatul moon. Unless the ruler of Mecca unsuccessful rukyat moon, then rukyat from another country can be used as a benchmark. Issues related technical rukyatul moon, for example, problem irtifa', should be resolved by consensus of experts to take the most correct opinion (sowab); Do not correct the notion that if rukyat contrary to the reckoning then taken was reckoning. The truth, which is still acceptable rukyat, during testimony meeting the requirements of the testimony. It takes a political institution that can unite the Muslims, it the Khilafah, the caliph's decision will be able to eliminate the difference of opinion, in accordance with the rules of fiqh "Imam Amrul yarfa'ul blunder."
\end{abstract}

Key words: New Moon, Rukyatul Hilal, Difference of Opinion

\section{A. Pendahuluan}

Doktrin Islam tentang kalender Kamariah hadir tidak dengan tibatiba, tetapi mengalir dalam alur komunikasi ilahiyah (wahyu) yang bertahap dan sarat dengan pesan spiritual dan visi hisab astronomi. Karena ketika al-Qur'an diturunkan pada abad ketujuh Masehi, kalender Kamariah sudah lama berlaku di kalangan masyarakat Arab. Yaitu semenjak periode Makkah, di mana belum turun ketentuan syariat yang mengaitkan aspek waktu pelaksanaannya dengan kalender ini, Nabi

${ }^{1}$ Dosen Fakultas Syari'ah IAI Ibrahimy Sukorejo Situbondo 
Muhammad SAW. sudah menerima pesan-pesan ilahiyah yang berkenaan dengan kalender Kamariah. ${ }^{2}$

Pesan-pesan itu terangkum dalam ayat-ayat al-Qur'an dan dikemas dengan bahasa simbolik yang mendalam, universal dan abadi, di antaranya, adalah :

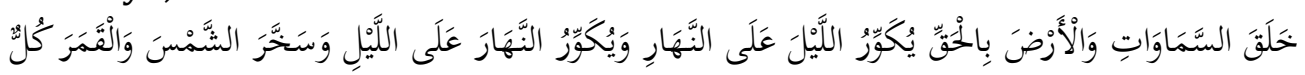

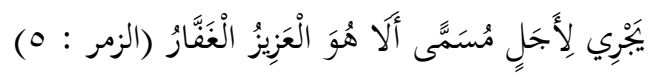

Dia menciptakan langit dan bumi dengan (tujuan) yang benar; Dia menutupkan malam atas siang dan menutupkan siang atas malam dan menundukkan matahari dan bulan, masing-masing berjalan menurut waktu yang ditentukan. Ingatlah Dia yang Maha Perkasa lagi Maha Pengampun. ${ }^{3}$

Dalam ayat lain disebutkan :

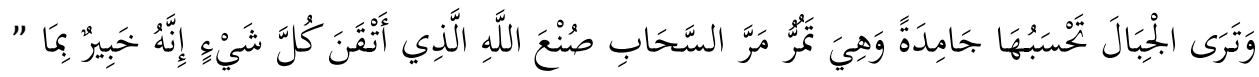

$$
\begin{aligned}
& \text { تَفْعَلُونَ (النمل : }
\end{aligned}
$$

Dan kamu lihat gunung-gunung itu, kamu sangka dia tetap diam di tempatnya, padahal dia berjalan sebagai jalannya awan. (Begitulah) perbuatan Allah yang membuat dengan kokoh tiap-tiap sesuatu; sesungguhnya Allah Maha Mengetahui apa yang kamu kerjakan. ${ }^{4}$

Pesan-pesan Makkah yang terangkum dalam ayat-ayat al-Qur'an di atas berbicara mengenai berbagai hal seputar fenomena ruang angkasa, yakni kawasan yang dikenal menjadi lahan perhatian disiplin fisika astronomi. Jadi jelas sekali terasa bahwa level dari hal-hal yang dibicarakan tersebut berada di luar jangkauan nalar masyarakat Arab pada waktu itu, sehingga dapat dikatakan "melampaui zamannya".

Pesan lain juga, misalnya, menggambarkan fenomena pergeseran malam dan siang di bumi dengan pola melingkar, yaitu malam menutupi

2 Abd. Salam, 2004. Ilmu Falak, Hisab Waktu Shalat, Arah Kiblat dan Kalender Hijriyah. Sidoarjo : Aqoba, hlm. 14

3 Departemen Agama RI, 2008. Al-Qur'an dan Terjemahannya, Surabaya : Al-Hidayah, hlm. 745 .

${ }^{4}$ Ibid, hlm. 605

102 JURNAL LISAN AL-HAL 
kawasan-kawasan yang tadinya mengalami siang dan sebaliknya. Jelas di sini ada isyarat tentang bulatnya bentuk planet bumi. Disisi lain juga menggambarkan bahwa gunung-gunung berjalan seperti awan. Gambaran tersebut mengisyaratkan tentang fenomena gerak revolusi bumi. ${ }^{5}$

Berbagai fenomena keteraturan gerak benda langit yang digambarkan itu lalu dirajut dalam simpul kehendak al-Khaliq; yaitu agar manusia (makhluk yang dinobatkan-Nya sebagai khalifah di bumi) mempunyai pengetahuan tentang kalender dan menguasai ilmu hisab. ${ }^{6}$ Maka sesudah aspek-aspek mendasar diberikan oleh pesan Makkah, pesan Madinah melengkapinya dengan segi-segi lain yang bersifat operasional. Sehingga ketika muncul pertanyaan tentang hilal, jawabannya diberikan melalui surat al-Baqarah 189:

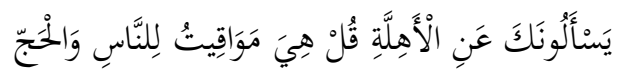

"Mereka bertanya kepadamu (Muhammad) tentang hilal-hilal. Katakanlah: Hilal-hilal itu adalah tanda-tanda waktu bagi manusia dan (bagi ibadat) haji ..."7

Dan ketika kaum musyrikin Makkah menunda tibanya bulan haram, dan menyisipkan bulan tambahan, maka direspons oleh pesan Madinah dengan penegasan dalam surat Taubah 36-37:

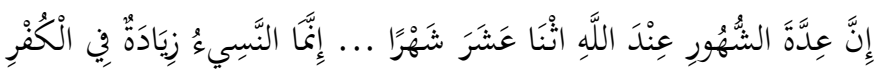

"Sesungguhnya bilangan bulan itu di sisi Allah adalah dua belas bulan" ... "Sesungguhnya menunda (bulan haram) itu tiada lain hanyalah menambah kekafiran belaka." 8

Rangkaian pesan yang terangkum dalam ayat-ayat al-Qur'an yang turun bertahap semenjak periode Makkah hingga periode Madinah tadi itu mengintrodusir sejumlah prinsip yang secara keseluruhan membentuk bangunan doktrin Islam tentang sistem kalender Kamariah.

Padahal, sebagai pemangku Qur'an, Nabi Muhammad SAW. pasti menyadari iradah ilahiyyah yang mencitakan penyusunan kalender Kamariah dengan pendekatan hisab astronomi itu. Namun kondisi aktual umat kala itu sungguh tidak mampu untuk mengatasinya.

Tidak klopnya pesan Makkah yang ideal di satu sisi dan kondisi

5 Moh. Ma'mur Tanudidjaja, 1996. Ilmu Pengetahuan Bumi Antariksa, Jakarta. hlm. 68

${ }^{6}$ Abdul Aziz Dahlan, dkk, 1999. Ensiklopedi Hukum Islam. Ikhtiar Baru: Jakarta, hlm. 35

${ }^{7}$ Departemen Agama RI, 2008. Al-Qur'an dan Terjemahannya, Surabaya: Al-Hidayah, hlm. 46

8 Ibid, hlm. 283 - 284 
umat yang masih dibelenggu keummian disisi lain mengharuskan menempuh jalan bertahap. Untuk ini Nabi Muhammad SAW. telah memulainya dengan membimbing mereka untuk tidak berspekulasi. Untuk mengetahui pergantian bulan, beliau menyuruh mereka mengobservasi hilal secara langsung. Kalau observasi gagal, beliau menyuruh menggenapkan umur bulan menjadi 30 hari .

\section{B. Peristiwa Hijrah sebagai Tonggak Kalender Islam}

Kalender hijriyah dimulai pada 1 Muharram tahun peristiwa Hijrah atau bertepatan dengan 15 Juli 662 M. Karena peristiwa hijrah Nabi Muhammad SAW. sendiri berlangsung pada bulan Rabi'ul Awal $1 \mathrm{H}$. atau September 622 M. Pemilihan peristiwa Hijrah ini sebagai tonggak awal penanggalan Islam memiliki makna yang amat dalam. Seolah-olah para sahabat yang menentukan pembentukan kalender Islam tersebut memperoleh petunjuk langsung dari Allah. Ia adalah ilham ilahiyah dengan maksud Allah ingin mengajarkan manusia bahwa 'peperangan' antara kebenaran dan kebatilan akan berlangsung terus. Kalender Islam mengingatkan kaum muslimin setiap tahun bukan kepada kejayaan dan kebesaran Islam, namun kepada pengorbanan Nabi dan sahabatnya dan mengingatkan mereka agar melakukan hal yang sama.

Hijrah sendiri dimulai sejak Rasulullah memerintahkan para sahabat untuk berangsur-angsur berangkat hijrah pada suatu malam di periode setelah kematian Abu Thalib. Diantara yang berangkat lebih awal adalah beberapa sepupu Nabi, Umar ra. beserta keluarganya, Usman ra. beserta keluarganya, Hamzah, dan Zaid. Rencananya Abu Bakar akan berangkat pada waktu itu juga, tetapi Rasulullah melarang beliau dan memerintahkan untuk menunggu petunjuk Allah mengenai keberangkatannya.

Lama setelah hijrah, ketika kaum muslimin menentukan penanggalan, malam hijrah pertama inilah yang ditetapkan sebagai tanggal pertama penanggalan Islam, yaitu 1 Muharram tahun 1 Hijriyah, yang bertepatan dengan tanggal 15 Juli 622 M. ${ }^{9}$

Sementara Rasulullah SAW sendiri baru berangkat hijrah bersama Abu Bakar ra. satu bulan kemudian, pada malam dimana terjadi pengepungan pemuda Quraisy di rumah Rasulullah, dan saat itu Ali tidur di tempat tidur Rasulullah menyediakan diri sebagai umpan. Ini terjadi

9 Abd. Salam, 2004. Ilmu Falak, Hisab Waktu Shalat, Arah Kiblat dan Kalender Hijriyah. Sidoarjo : Aqoba, hlm. 46

$104 \mid$ JURNAL LISAN AL-HAL 
pada saat hilal bulan baru muncul di langit Makkah. Jadi Rasulullah dan Abu Bakar ra. baru berangkat hijrah satu bulan setelah 1 Muharram, yaitu pada tanggal 1 Safar. Dan atas dasar ini pulalah bulan kedua dalam tahun Islam disebut Safar yang berarti perjalanan. ${ }^{10}$

\section{Perhitungan Kalender Islam Perspektif Syar'i}

Dalam Islam sistem penanggalan didasarkan pada peredaran faktual bulan mengelilingi bumi pada porosnya, sementara penanggalan Masehi berdasarkan peredaran faktual bumi mengelilingi matahari. Dalam al-Qur'an, cukup banyak ayat-ayat yang membicarakan peredaran bendabenda angkasa tersebut, antara lain: "Dia menyingsingkan pagi dan menjadikan malam untuk beristirahat, dan (menjadikan) matahari dan bulan untuk perhitungan. Itulah ketentuan Allah yang maha perkasa lagi maha mengetahui".11

Dalam ayat lain dinyatakan "Dialah yang menjadikan matahari bersinar dan bulan bercahaya dan ditetapkan-Nya manzilah-manzilah (tempat-tempat) bagi perjalanan bulan itu, supaya kamu mengetahui bilangan tahun dan perhitungan (waktu). Allah tidak menciptakan yang demikian itu melainkan dengan hak, Dia menjelaskan tanda-tanda (kebesaran-Nya) kepada orang-orang yang mengetahui". 12

Ada isyarat menarik dalam al-Qur'an di mana kata Qamar disebut 25 kali seluruhnya dengan bentuk mufrad, sedangkan kata hilal disebut hanya 1 kali namun dengan bentuk jamak. Ini isyarat bahwa pada permukaan Qamar yang satu bisa lahir fenomena hilal yang banyak. Menurut Wahbah al-Zuhaili, untuk penyebutan hilal digunakan bentuk jamak karena Qamar tampak dari bumi dalam berbagai ukuran. ${ }^{13}$

Qamar sendiri adalah benda langit yang gelap. Kalau ia tampak bersinar, itu hanyalah pantulan dari permukaannya yang tercahayai matahari dan menghadap ke bumi. Karena kedudukan bulan terhadap matahari dan bumi selalu berubah, maka seperdua permukaan bulan yang tercahayai matahari terus bergeser dari bagian yang menghadap ke bumi ke bagian lain yang membelakangi bumi, dan sebaliknya.

Karena itu dari kawasan observasi yang sama di permukaan bumi, keadaan penampakan bulan di langit terus berubah sepanjang waktu.

${ }^{10}$ Arfan Muhammad, 2006, Diktat Ilmu Falak, Untuk Kalangan Sendiri, hlm. 13

11 Ibid, hlm. 187

12 Ibid, hlm. 306

13 Al-Muqaddam, Muhammad bin Ismail, Ru`yatul Hilal Bayna Ar-Ru'yah AsySyar'iyyah wa Al-Falakiyah, www.saaid.net 
Posisi bulan yang sudah positif terhadap ufuk pada saat matahari terbenam tidak memastikan terjadinya penampakan hilal. 14

Pada saat matahari terbenam itu kadang hilal agak jauh dari matahari dan tampak dengan cahaya relatif terang. Kadang posisinya dekat dengan matahari dengan cahaya agak samar. Adakalanya pula hilal tidak tampak sama sekali. Pada rentang keadaan antara tampak dan tidak tampak itu dapat dicitakan adanya batas ambang visibilitas (hadd imkan al-ru'yah) hilal.15

Dalam suatu penelitian diketahui bahwa bumi dan matahari memiliki dua gerak yaitu rotasi dan revolusi, sebagaimana percikan makna ayat-ayat di atas. Rotasi matahari adalah perputaran matahari pada porosnya dari arah barat ke timur (atau dari arah timur ke barat secara semu). Sementara itu rotasi bumi adalah waktu yang diperlukan bumi dalam sekali putaran pada sumbunya hingga menyebabkan terjadinya siang dan malam. Melalui penelitian intensif, ditemukan bahwa matahari juga mengadakan revolusi, dimana al-Qur'an telah memberi isyarat tentang hal ini berdasarkan ayat di atas. ${ }^{16}$

Sementara itu revolusi bumi adalah proses bergeraknya bumi mengelilingi matahari dalam orbitnya dari arah timur ke barat, yang pada satu ketika bumi berada di titik terjauh dari matahari yang disebut dengan aphelion, dan pada ketika yang lain berada di titik yang terdekat dengan matahari yang disebut perihelion. Fenomena ini antara lain ditegaskan Allah SWT. dalam firman-Nya: "Dan kamu lihat gunung-gunung itu kamu sangka dia tetap ditempatnya, padahal ia berjalan sebagaimana jalannya awan. (Begitulah) perbuatan Allah, yang membuat dengan kokoh segala sesuatu. Sesungguhnya Allah maha mengetahui apa yang kamu kerjakan". ${ }^{17}$

Di sisi lain, dalam penanggalan Hijriah, perhitungan penanggalan dilakukan berdasarkan peredaran bulan di ekliptika selama 12 bulan. Satuan waktu bulan kamariah yang digunakan sebagai perhitungan penanggalan Hijriah adalah waktu bulan Synodic yang berjumlah 29,530589 hari, yaitu dengan menetapkan secara bergantian antara 30

14 Moh. Ma'mur Tanudidjaja, 1996. Ilmu Pengetahuan Bumi Antariksa, Jakarta. hlm. 156 hlm. 65

15 Syamsul Anwar, 2010. Hisab Awal Bulan Kamariah Tinjauan Syar'i, UIN Semarang,

16 Ibid. hlm. 145

17 Ibid, hlm. 165

106 JURNAL LISAN AL-HAL 
hari dan 29 hari. Adapun sisa pecahan 0,530589 hari dibulatkan menjadi satu hari dan ditambahkan kepada bulan Zulhijjah dengan berjumlah 30 hari. Tahun yang mendapat penambahan satu hari pada bulan Zulhijjah ini dinamakan tahun Kabisat. ${ }^{18}$

Disamping itu penetapan awal bulan kamariah dalam Islam dimulai dengan munculnya hilal, yaitu bulan sabit yang pertama kali terlihat yang terus membesar menjadi bulan purnama, menipis kembali dan akhirnya menghilang dari langit sebagaimana diisyaratkan surat al-Baqarah ayat 189 diatas. Belakangan, penentuan awal bulan dapat dilakukan dengan menggunakan perhitungan (hisab) astronomi. Satu tahun kamariah adalah jangka waktu yang dibutuhkan bulan mengelilingi bumi selama 12 kali putaran dengan rata-rata satu tahun lamanya 354 11/30 hari. Ilmu astronomi modern sudah sangat akurat memperhitungkan dan memperkirakan terlihatnya hilal dengan sangat teliti, tingkat ketelitian ini sudah lebih dari cukup untuk keperluan teknis penentuan awal-awal bulan kamariah. Namun dalam penentuan awal bulan Ramadhan, Syawal dan Zulhijjah persoalan tidak sederhana, hadis Nabi Saw. menyatakan awal dan akhir Ramadhan ditetapkan melalui pengamatan hilal (rukyat). ${ }^{19}$

Sebuah hadis Nabi Saw menyatakan "Puasalah kalian karena melihat hilal dan berbuka (berhari-raya)-lah karena melihat hilal, dan jika hilal tertutup oleh awan, lakukanlah pengkadaran". Jumhur ulama berpendapat bahwa hadis Nabi SAW. Di atas bermakna bahwa dalam memulai dan mengakhiri puasa dan hari raya hanya dengan melakukan pengamatan bulan sabit saja, yaitu terlihatnya hilal di awal Ramadhan dan Syawal sesuai dengan keumuman dan keliteralan hadis. Dengan kriteria jika hilal terlihat pada saat terbenam matahari tanggal 29 Sya'ban maka besok harinya adalah awal puasa, demikian pula jika hilal terlihat pada tanggal 29 Ramadhan maka besok harinya adalah hari raya dan rukyatul hilal mutlak dilakukan. Namun jika terdapat penghalang yang menutupi hilal, seperti mendung, maka pelaksanaan puasa dan atau hari raya harus ditunda sehari dengan menggenapkan (istikmâl) bilangan bulan Sya'ban dan atau Ramadhan menjadi 30 hari. Hal ini sesuai dengan pernyataan Nabi Saw yang menyatakan bahwa umur bulan itu adakalanya 30 hari dan adakalanya pula 29 hari. ${ }^{20}$

${ }^{18}$ Sjamsul Arifin, 1999. Ilmu Falak. STAIN Diponongoro, hlm. 87

19 Abd. Salam, 2004. Ilmu Falak, Hisab Waktu Shalat, Arah Kiblat dan Kalender Hijriyah. Sidoarjo : Aqoba, hlm.107

${ }^{20}$ Susiknan Azhari, 2001. Ilmu Falak Teori dan Praktek. Yokyakarta : Luzuardi. hlm. 


\section{Perhitungan Kalender Islam Perspektif Ilmu Pengetahuan}

Ketika kita amati ternyata pada hari hijrah, di Mekkah matahari baru terbenam sekitar pukul jam 23.00. Tapi pada jam 16:24 waktu setempat, matahari berada tepat di zenith Mekkah. Jadi jika saat itu kita ada di dekat Ka'bah, maka pada tanggal 1 Muharram tahun 1 Hijriyah akan terlihat matahari ada tepat di atas Ka'bah.

Peristiwa matahari ada di zenith Makkah memang bukan peristiwa luar biasa, karena terjadi dua kali setiap tahun. Tetapi dengan tiga variabel ini, simbolisasi-simbolisasi yang dikemukakan para ilmuan, dengan dibantu program simulasi langit, akan lebih bisa dipahami bahwa pada hari hijrah, Ka'bah memang tepat di bawah matahari, jadi dengan memulai perjalanan taubat, melalui hati yang telah kosong, manusia mi'raj (vertikal) menuju Allah. ${ }^{21}$

Menjelang matahari terbenam di tanggal tersebut di langit Mekkah, semakin nampak bahwa ternyata di hari itu posisi planet Mars, Neptunus, Uranus, Bulan, Merkurius, Venus, Saturnus dan Matahari (ditambah dengan bintang Regulus), nyaris ada dalam satu garis lurus dalam ruang pandang yang sempit, sekitar 45 derajat, jika dilihat dari bumi, khususnya wilayah Makkah.

Setelah matahari terbenam (kebetulan matahari terbenam paling duluan saat itu) mungkin saja kesejajaran posisi bintang ini akan nampak sedikit lebih jelas bagi para muhajirin, apalagi posisi bulan pada malam itu adalah bulan mati. Walaupun demikian, ilmuan tidak terlalu yakin mereka akan melihat ini, karena posisi beberapa planet yang relatif dekat dengan matahari.

Meski kurang memahami keistimewaan fenomena ini dari sudut pandang astronomi disamping memang lintasan semua planet di tatasurya kita (kecuali Pluto) gerak semu dari lintasannya akan nampak berdempetan jika dilihat dari langit bumi, tetapi tidak setiap saat planetplanet tersebut terlihat seakan-akan berjejer, berbaris pada satu sudut pandang yang hanya seluas sekitar 45 derajat di atas cakrawala. ${ }^{22}$

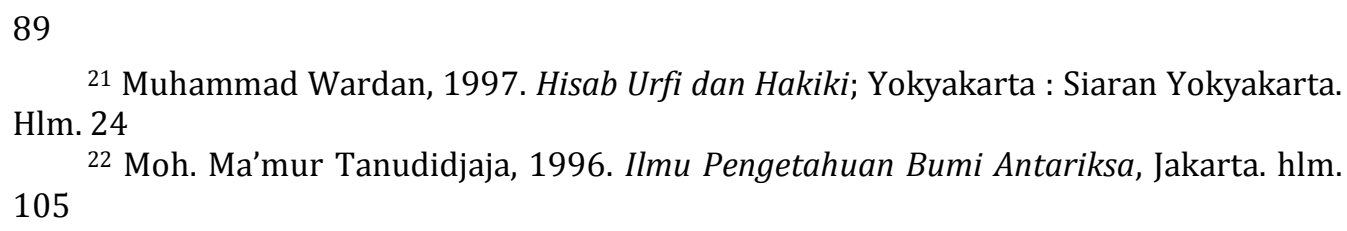


Keunikannya adalah fakta bahwa hari hijrah pertama, posisi matahari yang di atas Ka'bah (simbol qalb kosong yang telah menghadap Allah), juga dengan berbarisnya matahari, bulan yang masih gelap, yang posisinya tepat ada di tengah barisan beberapa planet, disatukan Allah pada hari itu. Apakah ini juga sebuah ayat yang menyimbolkan sesuatu yang berbicara tentang simbolisasi spiritual sesuatu?

Terjadinya dua peristiwa alam ini pada hari yang sama, di hari pertama Hijriyah, seakan-akan Allah memberi tanda melalui alam semesta, bahwa memang hari itu adalah hari yang khusus. Bagaikan Allah menggaris-bawahi hari itu dengan bukan hanya satu, tapi dua tanda di langit. Maa khalaqta haadza batilan. Tiada yang sia-sia dari apa yang Dia ciptakan. Allah membimbing para hamba-Nya hingga ke hal yang sekecilkecilnya, dan menundukkan alam semesta bagi para hamba-Nya yang bertaqwa.

Penentuan awal bulan Kamariah tidak terbatas hanya dengan rukyatul hilal, namun ada alternatif lain yang sederhana yakni ilmu hisab. Berdasarkan pengalaman ratusan tahun, keteraturan periodisitas fase-fase bulan diketahui dengan baik sehingga lahirlah ilmu hisab untuk menghitung posisi bulan dan matahari. Akurasinya pun terus ditingkatkan, hingga dalam ketepatan penentuan waktu awal bulan, yang hakikatnya ijtimak yang teramati, sampai detik-detiknya merupakan bukti yang dapat dicapai tak terbantahkan. ${ }^{23}$

Hisab dan rukyat punya kedudukan sejajar. Rukyat harus tetap digunakan karena itulah cara sederhana yang diajarkan Rasul. Hisab pun dijamin eksistensinya, karena Allah menjamin peredaran bulan dan matahari dapat dihitung.

Hisab merupakan hasil ijtihad yang didukung bukti-bukti pengamatan yang sangat banyak. Dalam hisab ada rumus-rumus astronomi yang dibuat berdasarkan pengetahuan selama ratusan tahun tentang keteraturan peredaran bulan dan matahari. Makin lama hasil perhitungannya makin akurat dengan memasukkan makin banyak faktor. Orang mempercayai hasil hisab karena didukung bukti-bukti kuat tentang ketepatannya, seperti hisab gerhana matahari yang demikian teliti sampai orde detik. Maka jaminan kebenarannya lebih kuat dari pada rukyat, karena orang lain bisa mengujinya dan pengamatan posisi bulan bisa membuktikannya. Namun, dalam hal penetapan awal bulan Kamariah tergantung kriteria yang digunakan dalam mengambil keputusan. Ada

\footnotetext{
${ }^{23}$ Abu Zaid, Bakar bin Abdullah, Hukmu Itsbat Awwal Asy-Syahr Al-Qamari wa Tauhid Ar-Ru yah, www.saaid.net
} 
yang berdasarkan wujudul hilal, ada juga yang berdasarkan imkan rukyat. 24

Sifat ijtihadiyah hisab dan rukyat memungkinkan terjadinya keragaman. Baik hisab maupun rukyat sama-sama berpotensi benar dan salah. Bulan dan matahari yang dihisab dan dirukyat masing-masing memang satu. Hukum alam yang mengatur gerakannya pun satu, sunnatullah. Tetapi, interpretasi orang atas hasil hisab bisa beragam. Lokasi pengamatan dan keterbatasan pengamatan juga tidak mungkin disamakan.

Bukti ilmiah yang bisa menguatkan kesaksian akan rukyatul hilal antara lain posisi hilal, bentuknya, serta waktu mulai teramati dan terbenamnya. Bukti ilmiah itu bisa diuji kebenarannya dengan rukyat harihari berikutnya. Bagi kalangan yang mempercayai rukyat terpandu hisab, bukti ilmiah itu bisa ditambah dengan hasil hisabnya. Hasil rukyat bisa segera dicocokkan dengan hasil hisabnya. Dengan kriteria hisabnya, kalangan ini bisa menolak kesaksian hilal bila dianggap meragukan. ${ }^{25}$

Ada beberapa langkah yang bisa digunakan dalam menentukan awal bulan Kamariah untuk menuju kesatuan. Pertama; pemakaian hisab global. Masalah teknis ilmiah relatif paling mudah diselesaikan. Rukyat bisa dibantu dengan hasil hisab untuk menentukan posisi hilal. Tetapi kepastian hilal bisa teramati atau tidak masih tergantung faktor cuaca yang di luar kemampuan manusia untuk mengatasinya. Dengan makin akuratnya hisab astronomi, hisab bisa dijadikan dasar pengambilan keputusan bukan sekedar alat bantu rukyat. Kriteria hisab bisa ditentukan berdasarkan pengalaman keberhasilan rukyat. Penyatuan kalender Islam secara internasional dengan pendekatan teknis ilmiah ini yang sudah dilakukan ahli hisab dan rukyat seluruh dunia, karena belum tentu semua negara mematuhi keputusan-keputusannya, termasuk Arab Saudi dan Indonesia.

Kedua, konfirmasikan setiap kesaksian rukyatul hilal. Kesaksian rukyat seringkali kontroversial yang menyebabkan munculnya perbedaan. Penyebabnya bisa karena rukyatnya tidak murni lagi, tetapi terpengaruh hasil hisab dengan metode lama yang tidak akurat. Penyebab lainnya adalah ketidaktahuan pengamat untuk membedakan hilal dan objek lain.

${ }^{24}$ Al-Hasun, Fahad bin Ali, Dukhul Asy-Syahr Al-Qamari Baina Ru yah Al-Hilal wa AlHisab Al-Falaki, www.saaid.net

25 Ibrahim, Salamun, 1995. Ilmu Falak Cara Mengetahui Awal Tahun, Awal Bulan, Arah Kiblat, Musim, dan Perbedaan Waktu, Surabaya : Pustaka Progressif, hlm. 76

110 JURNAL LISAN AL-HAL 
Untuk menghindarkan kesaksian yang kontroversial itu perlu disepakati kriteria untuk mengkonfirmasikannya, tidak cukup sekedar sumpah. Salah satu langkah yang sudah dilakukan oleh Kementerian Agama RI adalah menolak kesaksian hilal bila secara hisab yang akurat bulan sebenarnya sudah di bawah ufuk pada saat magrib. Kriteria lain yang bisa digunakan adalah posisi hilal dan bentuk hilal. Ahli astronomi dan ahli rukyat yang berpengalaman akan mengkonfirmasi benar-tidaknya kesaksian itu.

Ketiga, adakan lembaga antarpemerintah sebagai otoritas tunggal yang ditaati. Kesaksian hilal di suatu wilayah hanya bisa dijadikan dasar keputusan global bila ada otoritas tunggal pengambil keputusan. Selama belum ada otoritas tunggal yang dipercaya sebagai pengambil keputusan dan bisa mengumumkan ke seluruh dunia, kesaksian hilal itu malah akan memunculkan keputusan yang berbeda-beda karena informasinya tidak mungkin tersebar merata. Kesaksian hilal di Arab Saudi belum tentu yang terbaik, karena pelapornya mungkin juga orang awam yang berani di sumpah karena keyakinannya yang merasa benar telah menyaksikan hilal.

\section{E. Kesimpulan}

Kalender kamariah dapat disarikan sedikitnya dalam 5 item; Pertama, sistemnya mengacu pada manzilah Bulan, Kedua, pergantian siklus hari/tanggalnya mengacu pada moment terbenamnya Matahari. Ketiga; pergantian siklus bulannya mengacu pada kemunculan hilal; Keempat, pergantian siklus tahunnya mengacu pada paripurnanya masa 12 bulan; Kelima, pengetahuan tentang batas siklusnya digali dengan pendekatan yang tidak spekulatif, mulai dari fisis observasional (ru'yah) hingga fisis matematis (hisab astronomi).

Dengan meletakkan manzilah bulan sebagai acuan, syariat Islam membuka pintu bagi ilmu pengetahuan dan astronomi untuk berperan dalam penyusunan kalendernya. Dengan begitu peran buat disiplin astronomi itu dalam wilayah kerja ijtihad berada di kawasan hilir, yakni sebagai ijtihad litathbiqil ahkam (penerapan hukum) untuk menindaklanjuti hasil ijtihad lima'rifatil ahkam (pengenalan materi hukum) yang dimainkan oleh disiplin ilmu syariat di wilayah hulu.

Oleh karena batas siklus bulan dalam kalender kamariah menurut rumusan syariat adalah kemunculan hilal, maka peran yang dimainkan oleh pemangku disiplin astronomi atau ilmu pengetahuan adalah ijtihad merumuskan kriteria kemunculan hilal. 
Abdul Aziz Dahlan, dkk, Ensiklopedi Hukum Islam, Jakarta : Ikhtiar Baru

Abd. Salam, Ilmu Falak, Hisab Waktu Shalat, Arah Kiblat dan Kalender Hijriyah, Sidoarjo : Aqoba, 2004

Abu Zaid, Bakar bin Abdullah, Hukmu Itsbat Awwal Asy-Syahr Al-Qamari wa Tauhid Ar-Ru'yah, www.saaid.net

Ad-Dusari, Jabar bin Shalih, Al-Hisab Awwalan, Laa Al-Marashid wa AlAqmar, www.saaid.net

Al-Hasun, Fahad bin Ali, Dukhul Asy-Syahr Al-Qamari Baina Ru yah Al-Hilal wa Al-Hisab Al-Falaki, www.saaid.net

Al-Muqaddam, Muhammad bin Ismail, Ru yatul Hilal Bayna Ar-Ru yah AsySyar'iyyah wa Al-Falakiyah, www.saaid.net

Arfan Muhammad, Pedoman Ilmu Falak; Diktat untuk kalangan sendiri, 2006

Departemen Agama RI, Alquran dan Terjemahannya, Surabaya : AlHidayah, 2008

Djambek, Saadoe'ddin, Hisab Awal Bulan, Jakarta : Tinta mas, 1976

Ditbinperais, Pedoman Penentuan Arah Kiblat, Jakarta, 1985

Ibrahim, Salamun, Ilmu Falak Cara Mengetahui Awal Tahun, Awal Bulan, Arah Kiblat, Musim, dan Perbedaan Waktu, Surabaya : Pustaka Progressif, 1995

Moh. Ma'mur Tanudidjaja, Ilmu Pengetahuan Bumi dan Antariksa, Jakarta, 1996

Muhammad Wardan, Hisab Urfi dan Hakiki; Siaran Yokyakarta, 1997

Sjamsul Arifin, Ilmu Falak, STAIN Diponorogo, 1999

Syamsul Anwar, Hisab Awal Bulan Kamariah Tinjauan Syar'i, UIN Semarang, 2010

Susiknan Azhari, Ilmu Falak Teori dan Praktek, Yokyakarta, Luzuardi, 2001

Zubairi Umar, Al-Khulashah al-Wafiyyah; Menara Kudus, 1971

112 JURNAL LISAN AL-HAL 
